\title{
Epistemiczna wartość doświadczenia zmysłowego. Wilfrid Sellars versus John McDowell
}

\author{
Michał Bochen \\ https://orcid.org/0000-0002-6128-4348
}

Artykuł jest próbą refleksji nad epistemiczną wartością doświadczenia zmysłowego. Biorąc za przykład pojęciową treść percepcji Johna McDowella, staram się wykazać, że krytyka empiryzmu dokonana przez Wilfrida Sellarsa nie neguje całkowicie sensowności idei fundacjonalistycznej epistemologii. Uważam tym samym, że możliwe jest zrehabilitowanie wartości percepcji w uzasadnieniu wiedzy po przeformułowaniu koncepcji doświadczenia zmysłowego. Jeżeli bowiem przyjmiemy ideę pojęciowej treści percepcji oraz jej konsekwencję w postaci potencjalnej propozycjonalności treści doświadczenia, uda się nam wykazać, że percepcja może wchodzić w racjonalny (a nie wyłącznie przyczynowy) stosunek z przekonaniami żywionymi przez podmiot. To zaś uzasadnia idee fundacjonalistycznej epistemologii zgodnie z którymi, wiedza posiada zewnętrzne oraz epistemicznie wartościowe ugruntowanie.

Słowa kluczowe: John McDowell, Wilfrid Sellars empiryzm i filozofia umysłu, mind and world, pojęciowa treść percepcji, fundacjonalizm, epistemologia, empiryzm, wartość, logiczna przestrzeń racji

W pracy Filozofia a zwierciadło natury Richarda Rorty’ego pada sugestia, że jeżeli odrzucimy pomysł o fundamencie wiedzy, który ma postać „uprzywilejowanych treści w polu świadomości”, to musimy przyjąć wniosek, że epistemologia

MICHAŁ BOCHEN, mgr filozofii; adres do korespondencji: Instytut Filozofii UMCS, Pl. M. Curie-Skłodowskiej 4, 20-031 Lublin; e-mail: faumaks@gmail.com 
nie ma racji bytu ${ }^{1}$. Odrzucenie idei o treściach tego rodzaju powinno być konsekwencją przyjęcia krytyki pojęcia analityczności przedstawionej przez Willarda Van Ormana Quine’a oraz krytyki „daności” (w szczególności tej doświadczeniowej) dokonanej przez Wilfrida Sellarsa. Ustalenia obu tych autorów, zdaniem Rorty'ego, pokazują, że poszukiwanie kartezjańskiego „punku archimedesowego” w epistemologii jest niemożliwe do zrealizowania. Pozostaje nam jedynie rozważanie pojęcia wiedzy jako dialogu prowadzonego między podmiotami. Jednak to nie będzie już epistemologią, lecz hermeneutyką ${ }^{2}$.

Konkluzje Rorty'ego, w których mowa jest o końcu epistemologii wydają się jednak przedwczesne. Należy zwrócić uwagę na fakt, że jeżeli dokonamy opisu, w którym bezpośrednie treści reprezentujące świat (a więc treści doświadczenia zmysłowego) są epistemicznie wartościowe, uda się nam uratować przynajmniej epistemologie fundacjonalistyczne empirystycznego rodzaju. Jest to zaś możliwe nawet jeżeli zachowamy wnioski z krytyki empiryzmu dokonanej przez Sellarsa oraz Donalda Davidsona. Tym samym uważam, że możliwe jest zrehabilitowanie wartości doświadczenia zmysłowego w uzasadnieniu wiedzy, pozostając na gruncie normatywnie zorientowanego naturalizmu ${ }^{3}$.

Doświadczenie zmysłowe będzie posiadać epistemiczną wartość, gdy uda się wykazać, że stany percepcyjne mogą stanowić grunt uzasadniający wiedzę propozycjonalną. Co za tym idzie, pytanie o epistemiczną wartość doświadczenia jest pytaniem o to, czy wiedza może posiadać zewnętrzne wobec niej ugruntowanie. Nie jest to więc problem, czy doświadczenie zmysłowe stanowi przyczynę naszej

${ }^{1}$ Por. Richard Rorty, Filozofia a zwierciadło natury, tłum. Michał Szczubiałka (Warszawa: Wydawnictwo Spacja: Fundacja Aletheia, 1994), 188.

${ }^{2}$ Tamże, 281-282.

${ }^{3}$ Mam tu na myśli koncepcję „naturalizmu z normatywnym zwrotem” (naturalism with a normative turn), jak James R. O'Shea określa filozofię Wilfrida Sellarsa. W ramach swojej koncepcji Sellars przyjmuje, że istnieją nieredukowalne do faktów empirycznych fakty epistemiczne oraz inne fakty związane pojęciowymi zdolnościami podmiotu. Należą one do „logicznej przestrzeni racji”, która posiada normatywny charakter. Jednocześnie Sellars przyjmuje prymat obrazu naukowego - nauka jest dla niego „miarą wszystkich rzeczy”. Por. James R. O'Shea, „On the Structure of Sellar's Naturalism with a Normative Turn”, w: Empiricisim, Perceptual Knowledge, Normativity, and Realism, red. Willem A. deVries (Oxford: Oxford University Press 2009), 188-210; oraz James R. O'Shea, Wilfrid Sellars: Naturalism with a Normative Turn (Cambridge: Polity Press 2007). Dla niniejszych rozważań najistotniejsze jest to, że Sellars wyróżnia „logiczną przestrzeń racji”, która nadaje pojęciowym zdolnościom człowieka swoisty charakter i ze względu na ten charakter są one nieredukowalne do tego, co przyrodnicze. Nadanie im takiego charakteru generuje jednak problemy z ugruntowaniem wiedzy dyskursywnej na doświadczeniu zmysłowym, które, jako przynależne do świata empirii, nie jest częścią „logicznej przestrzeni racji”. 
wiedzy (co do tego, wydaje się, nie ma licznych kontrowersji), lecz czy może być traktowane jako racja za przyjęciem przekonania o stanie rzeczy. Niebanalny charakter tych kwestii ujawni przytoczenie dwóch stanowisk uważanych za krytyki fundacjonalistycznych epistemologii: „mitu danych” Wilfrida Sellarsa oraz jego konsekwencji w postaci krytyki dualizmu schematu i treści Donalda Davidsona. Modelowym przykładem epistemologii fundacjonalistycznej jest zaś empiryzm. Przyjmuję, że krytykowanym przez Sellarsa i Davidsona empiryzmem jest ta jego postać, która w kwestii struktury wiedzy, zakłada istnienie przekonań bazowych, które nie są uzasadnione na mocy żadnych innych przekonań, lecz przez doświadczenie zmysłowe $e^{4}$. Jednocześnie postaram się pokazać, że koncepcja pojęciowej treści percepcji Johna McDowella jest próbą resuscytacji epistemicznej wartości doświadczenia zmysłowego. McDowell odrzuca koncepcję doświadczenia jako biernego doznawania, które jako dzielone przez człowieka ze zwierzętami - jest czymś irracjonalnym. Proponuje on w zamian twierdzenie, że doświadczenie zmysłowe ma charakter pojęciowy, co oznacza, że pojęciowe zdolności obecne na poziomie formułowania sądów również uczestniczą podczas postrzegania. Taki charakter doświadczenia sprawia zaś, że może je pojmować jako epistemicznie wartościowe i stanowiące ugruntowanie wiedzy propozycjonalnej.

\section{Uzasadnianie a doświadczenie zmysłowe}

Wiedzę, która wymaga uzasadnienia, rozumiem jako relację pomiędzy podmiotem a sądem wyrażonym $\mathrm{w}$ formie zdania oznajmującego. Przyjmuję zatem propozycjonalną teorię wiedzy, według której wiedza jest zbiorem zdań i wyraża się w schemacie „S wie, że $A$ ”. Pojęcie uzasadnienia odnosi się zaś do jednego z warunków wymienionych w klasycznej definicji wiedzy: wiedzieć coś to posia-

\footnotetext{
${ }^{4}$ Jest to zatem klasyczna postać empiryzmu, w ramach której przyjmuje się, że wiedza empiryczna posiada podstawę $\mathrm{w}$ wiedzy wywiedzionej bezpośrednio $\mathrm{z}$ doświadczenia zmysłowego, co ze swojej strony nie wymaga posiadania przez podmiot jakiejkolwiek wiedzy. Por. John McDowell, „Why is Sellars Essay Called »Empiricism and Philosophy of Mind «?,” w: Empiricisim, Perceptual Knowledge, Normativity, and Realism, red. Willem A. deVries (Oxford: Oxford University Press 2009), 9-32.

${ }^{5}$ Por. Jan Woleński, Epistemologia: poznanie, prawda, wiedza, realizm (Warszawa: Wydawnictwo Naukowe PWN, 2005), 335.
} 
dać prawdziwe i właściwie uzasadnione przekonanie. Uzasadnienie jest wskazaniem na racje stojące za przyjęciem tego, że żywione przez nas przekonanie jest zgodne ze stanem rzeczy.

W pracy Empiryzm i filozofia umysłu, odnosząc się do jednej z teorii wskazujących na uzasadnienie wiedzy empirycznej, Sellars krytykuje pogląd głoszący, że „fakty epistemiczne mogą być zanalizowane bez reszty [...] na fakty nieepistemiczne"'. Rozważa tutaj koncepcję przyjmowaną w ramach stanowisk, przedstawiających wiedzę empiryczną jako wspierającą się na fundamencie nieinferencyjnej wiedzy o faktach pewnego rodzaju ${ }^{7}$. Takimi stanowiskami mogą być na przykład teorie danych zmysłowych, wedle których fundamentalnym, najprostszym, nieredukowalnym poziomem wiedzy jest wiedza o faktach bezpośrednio dotyczących „zdarzeń” na poziomie doświadczenia zmysłowego. Sellars zauważa jednak, że wiedza o danych zmysłowych, wyrażona w zdaniach typu „ $X$ jest barwną plamą, która jest doznawana” stanowi wiedzę o indywiduach, natomiast „znane” we właściwym sensie (nawet nieinferencyjnie) jest to, co jest faktem o formie „coś jest takie-a-takie” lub „coś pozostaje w pewnej relacji do czegoś innego”, czyli to, co wyrażane jest w postaci propozycjonalnej. Zwolennik danych zmysłowych zdaniem Sellarsa - staje przed wyborem: albo uzna, że jeżeli doznawanie jest doznawaniem barwnych plam, dźwięków i tym podobnych, to nie jest ono poznaniem, albo że jest formą poznania i to fakty są doznawane, nie zaś indywidua.

To pokazuje różnicę pomiędzy wiedzą o danych zmysłowych a wiedzą o charakterze propozycjonalnym: pierwszy rodzaj wiedzy jest wiedzą wyłącznie odbiorczą, wolną od jakiegokolwiek rodzaju konceptualizacji materiału doznaniowego. Drugi rodzaj wiedzy, wiedza o faktach, będzie wiedzą konstruowaną z pojęć, chociaż w dalszym ciągu posiadającą charakter nieinferencyjny ${ }^{8}$. Przykładem pierwszego rodzaju wiedzy będzie wiedza o poszczególnych plamach barwnych, znajdujących się w polu widzenia podmiotu (powiedzmy: czarnych, czerwonych, zielonych), zaś wiedzą drugiego rodzaju będzie wiedza o postrzeganych przedmiotach i relacjach między nimi (np. biedronce znajdującej się na liściu). Drugi rodzaj

${ }^{6}$ Wilfird Sellars, „Empiryzm i filozofia umysłu”, tłum. Jarosław Gryz, w: Empiryzm współczesny, red. Barbara Stanosz (Warszawa: Wydawnictwo Uniwersytetu Warszawskiego, 1991), 175.

${ }^{7}$ Tamże.

${ }^{8}$ Wiedza wyrażona w zdaniu „Ten liść jest zielony”, chociaż wymaga znajomości użycia określonych pojęć, nie wymaga przeprowadzenia nawet najprostszego wnioskowania. Formułowanie takiej wiedzy jest zatem umiejętnością nabytą, albo inaczej mówiąc, stanowi rodzaj „wiedzy-jak”. Por. tamże, 223. 
wiedzy, chociaż nie jest skutkiem procesu wnioskowania, wymaga posiadania określonych pojęć. W naszym przykładzie tymi pojęciami są: „biedronka”, „znajdowanie się na” oraz „liść”. Zdobywanie wiedzy o barwach będzie umiejętnością wrodzoną, ponieważ ogranicza się wyłącznie do bycia świadomym określonej barwy (oznacza to, że jest stanem całkowicie biernym), podczas gdy formułowanie wiedzy o faktach wymaga zdobycia odpowiedniego uposażenia pojęciowego - jest tym samym umiejętnością nabytą ${ }^{9}$ Sellars krytykuje oczywiście takie rozróżnienie, wskazując między innymi na to, że samo rozpoznanie barw również wymaga pojęciowych zdolności ${ }^{10}$.

Zdaniem Sellarsa, powyższe kłopoty wynikają z pomieszania dwóch idei. Pierwszą jest idea o istnieniu zdarzeń wewnętrznych w postaci wrażeń, które „przytrafiają się” zarówno człowiekowi, jak i zwierzęciu i które do zaistnienia nie wymagają uposażenia pojęciowego. Bez takich wrażeń jednak, co podkreśla Sellars, niemożliwe byłoby widzenie, że obserwowana przez nas rzecz charakteryzuje się określonymi własnościami. Wrażenia są więc niezbędne w procesie poznania: „niemożliwe byłoby widzieć np., że przednia powierzchnia przedmiotu fizycznego jest czerwona i trójkątna, czy też słyszeć, że pewien fizyczny dźwięk ma wysokość cis" ${ }^{\prime 1}$. Druga zaś idea głosi, że „istnieją zdarzenia wewnętrzne, stanowiące nieinferencyjną wiedzę o tym, że pewne rzeczy są np. czerwone czy mają wysokość cis"12. Ten poziom poznania stanowi wiedzę we właściwym sensie, ponieważ ma postać propozycjonalną oraz wymaga znajomości znaczenia odpowiednich pojęć. „Pomieszanie” tych dwóch idei polega na tym, że odbiorczej i wrodzonej umiejętności doznawania nadaje się własności charakterystyczne dla wiedzy, która jest tworem wyłącznie pojęciowym. Jeżeli zaś wiedza o danych zmysłowych w założeniu ma całkowicie niepojęciowy charakter (bo umiejętność takiego poznawania musi być umiejętnością wrodzoną, jeżeli chcemy zachować genetyczny charakter

${ }^{9}$ Tamże, 178.

${ }^{10}$ Wskazuje na to, konstruując tak zwaną „sprzeczną triadę”. Znaczenie owej triady można wyrazić w następujący sposób: jeżeli wiedza o danej zmysłowej ma postać „s wie, że $x$ jest czerwone” oraz, jak zostało powiedziane, zdobywanie takiego rodzaju wiedzy jest umiejętnością wrodzoną, zaś zdolność formułowania wiedzy o postaci „ $x$ jest $F$ ” jest nabyta, to pojawia się tutaj sprzeczność. Wynika $z$ tego bowiem, że umiejętność formułowania wiedzy o danych zmysłowych jest jednocześnie nabyta i wrodzona. Por. tamże, 179; a także Willem A. deVries, Timm Triplett, Knowledge, Mind and the Given (Indianapolis: Hackett Publishing Company, Inc., 2000), 14.

${ }^{11}$ Sellars, „Empiryzm i filozofia umysłu”, 180.

12 Tamże. 
empiryzmu), to nadawanie jej formy propozycjonalnej: „X jest plamą barwną, która jest doznawana" jest bezzasadne. Niemożliwe jest zachowanie propozycjonalnego charakteru poznania bez założenia, że uczestniczą w nim nabyte przez podmiot pojęcia. Według Sellarsa, należy oddzielić te dwie idee, a tym samym przyjąć, że: „nie ma powodu zakładać, iż posiadanie wrażenia [...] jest faktem poznawczym czy epistemicznym"13. Doświadczenie zmysłowe jest w takim ujęciu wyłącznie doznaniową, wrodzoną, a przez to nieepistemiczną aktywnością.

Sellars oddziela doświadczenie zmysłowe od wiedzy, nawet jeżeli chodzi o wiedzę obserwacyjną, bezpośrednio odniesioną do tego, co doznawane. Chociaż doświadczenie zmysłowe jest konieczne, by posiadać wiedzę o tym, że, powiedzmy, widzę czerwoną, kropkowaną powierzchnię, to nie może stanowić przesłanki, która uzasadniałaby przyjęte przeze mnie przekonanie na temat widzianego przedmiotu. Jak zostało pokazane wyżej, sformułowanie jakiegokolwiek przekonania wymaga pojęciowych zdolności albo dodatkowej wiedzy, która dla

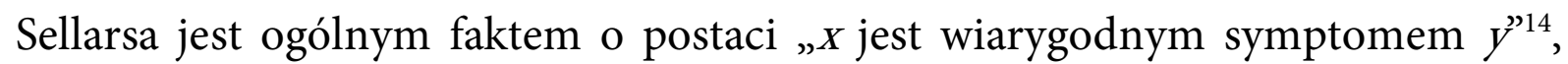
który wskazuje na pewne wcześniej doświadczone prawidłowości. Przeczy to zaś podstawowym założeniom genetycznego empiryzmu, które mówią, że nim poznamy fakt ogólny musimy uprzednio doświadczyć określonej liczby faktów jednostkowych. W sytuacji zaś, którą przedstawia Sellars, niemożliwe jest bezpośrednie poznanie faktu, nawet takiego, który mówiłby o doznaniu przez podmiot określonej plamy barwnej. Doświadczenie zaś, jako pomost łączący podmiot ze światem, a więc coś, co z zasady musi być bezpośrednie, nie może mieć charakteru propozycjonalnego. $Z$ tego wynika, że nie może stanowić uzasadnienia dla przekonania, bowiem, jak pisze Sellars w jednym z najbardziej płodnych zdań eseju: „charakteryzując zdarzenie czy stan jako poznawanie, nie dostarczamy temu zdarzeniu czy stanowi opis empirycznego; umieszczamy go w logicznej przestrzeni racji, uzasadnienia i bycia zdolnym do uzasadnienia tego, co ktoś mówi”"15.

Logiczna przestrzeń racji stanowi dla Sellarsa jedyną domenę, w której możliwa jest relacja uzasadniania i bycia uzasadnionym. Mówiąc o uzasadnieniu, mówimy o nim w kategoriach normatywnych, a więc o poprawnym, bądź niepoprawnym przyjęciu danego przekonania względem pewnych poznanych przez nas ra-

\footnotetext{
${ }^{13}$ Tamże.

${ }^{14}$ Tamże, 223.

15 Tamże, 224.
} 
cji. Mówiąc zaś o doznaniach, dokonujemy empirycznego opisu - w opisie empirycznym, który jest domeną relacji wyłącznie przyczynowych, nie ma miejsca na normatywność, a tym samym na uzasadnienie naszych przekonań ze względu na pewne racje. Mit danych polega więc na tym, że przyjmujemy w naszym opisie, iż pewne zdarzenia na poziomie empirycznym (doznania) mogą wyjaśniać zdarzenia epistemiczne (przekonania), zaś przejście pomiędzy tymi poziomami jest właśnie mitem. Jest to dla Sellarsa błąd tego rodzaju (i wagi), co błąd naturalistyczny w etyce ${ }^{16}$ - również tutaj następuje „pomieszanie” poziomu empirycznego i normatywnego.

Davidson w duchu wyżej przedstawionych uwag formułuje zaś swoją krytykę dualizmu schematu pojęciowego i treści. Dualizm ten stanowi według niego trzeci dogmatu empiryzmu, który pociąga za sobą dwa pozostałe przedstawione przez Quine'a. Odrzucenie trzeciego dogmatu ma wiązać się zaś z całkowitym odrzuceniem empiryzmu. Koncepcja Davidsona może być zatem odczytywana jako konsekwencja „mitu danych” Sellarsa. Davidson powie już explicite, że mitem jest twierdzenie, iż uzasadniając sąd wykraczamy poza schemat pojęciowy. Pisze: „[...] żadna rzecz, nie czyni zdań i teorii prawdziwymi: ani doświadczenie, ani pobudzenia nerwowe, ani świat"17. Uzasadnienie odbywa się zatem wyłącznie w ramach schematu pojęciowego: „»Moja skóra jest ciepła« jest prawdziwe wtedy i tylko wtedy, gdy moja skóra jest ciepła. Nie ma tu mowy o fakcie, świecie, doświadczeniu, czy świadectwie"18. Z tego powodu - jak gdzie indziej napisze Davidson - „[...] nic nie może być uznane za rację dla utrzymania przekonania, z wyjątkiem innego przekonania"19. Sfera uzasadniania jest zatem ograniczona wyłącznie do sfery pojęciowej - do Sellarsowskiej logicznej przestrzeni racji. Brak racjonalnego przejścia pomiędzy niepojęciowymi danymi a wiedzą według Davidsona podważa ostatni bastion empiryzmu. Wiedzę, według koherencjonistycznej kon-

16 Tamże, 175.

${ }^{17}$ Donald Davidson, „O pojęciu schematu pojęciowego,” w: Empiryzm współczesny, red. Barbara Stanosz (Warszawa: Wydawnictwo Uniwersytetu Warszawskiego, 1991), 292.

18 Tamże.

19 „nothing can count as a reason for holding belief except another belief”; Donald Davidson, „A Coherence Theory of Truth and Knowledge”, w: Subjective, Intersubjective, Objective, red. Donald Davidson (Oxford: Clarendon Press, 2001), 141. Jeśli nie podano inaczej, wszystkie teksty obcojęzyczne w tłumaczeniu autora. 
cepcji Davidsona, możemy porównać do sieci nawzajem wspierających się przekonań, która kontrastuje z fundacjonalistycznym obrazem wiedzy jako budowli, wznoszącej się na fundamencie bazowych przekonań. Taka propozycja zachowuje również Sellarsowski charakter w tym sensie, że głosi, iż doświadczenie zmysłowe stanowi jedynie etap poprzedzający przekonanie w porządku przyczynowym, lecz nie epistemicznym.

Z quasi-metafizycznego punktu widzenia możemy powiedzieć, że koncepcje Sellarsa i Davidsona dzielą rzeczywistość na logiczną przestrzeń racji i to, co znajduje się na poziomie świata empirycznego. Taki dualizm pociąga za sobą twierdzenie, że przestrzeń racji jest sui generis i nie jest redukowalna do tego, co przyrodnicze. Nasze myślenie, formułowanie przekonań i uzasadnianie, czyli, ogólnie rzecz biorąc, to, co normatywne, nie może być całkowicie zredukowane do procesów czysto fizycznych. Według koncepcji Sellarsa, jest to poziom rzeczywistości o takim samym stopniu realności, co rzeczywistość przyrodnicza. Konsekwencją takich ustaleń jest jednak fakt, że nie możemy przyjąć, iż doświadczenie zmysłowe, jako to, co dzielone przez człowieka ze zwierzętami, może posiadać jakąkolwiek wartość dla uzasadnienia wiedzy. Musimy jednak w odniesieniu do tego zadać pytanie: jak możliwe jest istnienie relacji pomiędzy wiedzą i światem, skoro przepaść znajdująca się pomiędzy nimi jest nieprzekraczalna nawet przez doświadczenie zmysłowe? W moim przekonaniu jest to pytanie, które stanowi punkt wyjścia dla rozważań Johna McDowella.

„Minimalny empiryzm” jako epistemologiczny model idealny

Omówienie propozycji McDowella rozpocznę od ogólnych rozważań z początkowych fragmentów Mind and World, przechodząc zaś do omawiania pojęciowej treści percepcji, posłużę się w głównej mierze jego późniejszym artykułem Avoiding the Myth of the Given. Wybór ten podyktowany jest faktem, że w rzeczonym artykule McDowell dokonuje ważnej modyfikacji swojej koncepcji, która jednak nie stoi w sprzeczności z ogólnym zamysłem Mind and World. Wart uwagi jest również fakt, że w obu przypadkach stanowisko McDowella jest w rzeczywistości odczytaniem propozycji teoretycznych Kanta z Krytyki czystego rozumu. $\mathrm{W}$ moim przekonaniu nie świadczy to o niewielkiej oryginalności propozycji 
McDowella, lecz o uczciwości wobec historii filozofii, której w rzetelnym, filozoficznym badaniu nie można nie docenić. Kant w swoim dziele w bardzo drobiazgowy sposób rozrysował możliwy obszar epistemologicznego badania, który w mniej lub bardziej ewidentnej postaci obecny był w różnych, nawet najbardziej „niekantowskich” teoriach poznania. Z tego powodu, jak pisze Kenneth R. Westphal w artykule Contemporary Epistemology: Kant, Hegel, McDowell: „Można napisać wyczerpującą historię epistemologii badając relację między tym, co Kant nazywał naszym intelektem oraz naszą naocznością"20. Z tego powodu konieczne będą również częste odwołania w dalszej części artykułu do filozofa z Królewca.

W pierwszym rozdziale Mind and World Johna McDowella ujawniony zostaje dylemat, dotyczący uzasadnienia przekonania odnoszącego się do doświadczenia, który można wyrazić w następujący sposób:

(i) uzasadnienie przekonania empirycznego może odbywać się wyłącznie w ramach przestrzeni racji,

lecz:

(ii) przekonanie empiryczne dotyczy tego, co znajduje się poza przestrzenią racji.

McDowell akceptuje ustalenia Sellarsa i Davidsona, że w uzasadnianiu nie wykraczamy poza logiczną przestrzeń racji. W przeciwnym bowiem razie oznaczałoby to, że logiczna przestrzeń racji wykracza poza to, co pojęciowe. McDowell w następujący sposób ujmuje sedno tego stanowiska: „nie możemy zrozumieć relacji na mocy których sąd jest uzasadniony, inaczej niż relacji znajdujących się w przestrzeni pojęć: relacji takich jak implikacja albo uprawdopodobnianie"21. Relacje, które są obecne w procesie uzasadniania, czyli relacje, w jakie wchodzą ze sobą sądy logiczne należą wyłącznie do tego, co dyskursywne. $Z$ tego powodu, poszukiwanie racji nie sięga poza domenę tego, co pojęciowe. Pomimo tych wniosków przejętych od Sellarsa i Davidsona, autor Mind and World nie może zgodzić

${ }^{20}$ ”One could write a complete history of epistemology by examining the relation between what Kant called our understanding and our sensibility”; Kenneth R. Westphal, „Contemporary Epistemology: Kant, Hegel, McDowell”, w: John McDowell: Experience, Norm, and Nature, red. Jakob Lindgaard (Malden: Blackwell Publishing Ltd., 2008), 275.

${ }^{21}$,we cannot really understand the relations in virtue of which a judgment is warranted except as relations within the space of concepts: relations such as implication or probabilification"; John McDowell, Mind and World (Cambridge: Harvard University Press, 1996), 8. 
się na całkowite odrzucenie idei epistemicznej wartości doświadczenia zmysłowego. Taka jego wartość jest bowiem warunkiem sensowności tego, że umysł może wchodzić w epistemicznie znaczącą relację ze światem. Albowiem, zdaniem McDowella, relacja umysłu i świata opiera się na relacji odpowiedniości doświadczenia zmysłowego i myślenia. McDowell pisze, używając metafory zapożyczonej od Quine'a ${ }^{22}$, że „doświadczenie musi konstytuować trybunał zapośredniczający sposób, w jaki nasze myślenie jest odpowiednie względem tego, jakie są rzeczy"23. W tym streszcza się idea "minimalnego empiryzmu” - relacja umysłu i świata opiera się na doświadczeniu zmysłowym, bowiem to na tym poziomie poznanie świata styka się ze swoim przedmiotem.

Istotny jest fakt, że zdaniem autora Mind and World relacja umyst-świat nie posiada wyłącznie przyczynowego charakteru, lecz również normatywny. Przekonanie albo sąd jest bowiem postawą, która jest właściwie bądź niewłaściwie przyjęta względem tego, czy rzeczy są lub nie są takie-a-takie ${ }^{24}$. Przekonanie jest zatem postawą wobec stanu rzeczy - i z tego powodu może podlegać wartościowaniu: jest bowiem właściwą lub niewłaściwą postawą wobec świata.

Również i tutaj widoczne są Sellarsowskie inspiracje koncepcji McDowella. Sellars w eseju Philosophy and the Scientific Image of Man pisze, że „[b]yć zdolnym myśleć to być zdolnym zmierzyć swoją myśl wedle norm poprawności, stosowności, dowodu"25. Poddawanie ewaluacji swoich przekonań jest dla niego istotowo związane z aktywnością myślenia. Normy, wedle których poddajemy weryfikacji naszą wiedzę rozumie zaś Sellars w kontekście reguł wyznaczanych przez

${ }^{22}$ Por. Willard Van Orman Quine, Z logicznego punktu widzenia, tłum. Barbara Stanosz (Warszawa: PWN, 1969), 63.

${ }^{23}$ "experience must constitute a tribunal, mediating the way our thinking is answerable to how things are"; McDowell, Mind and World, xii.

${ }^{24}$ Tamże, xii: „A belief or judgment to the effect that things are thus and so-a belief or judgment whose content (as we say) is that things are thus and so-must be a posture or stance that is correctly or incorrectly adopted according to whether or not things are indeed thus and so".

${ }^{25}$ "To be able to think is to be able to measure one's thoughts by standards of correctness, of relevance, of evidence." Wilfrid Sellars, "Philosophy and the Scientific Image of Man," w: In the Space of Reasons. Selected Essays of Wilfrid Sellars, red. Kevin Scharp, Robert B. Brandom (Cambridge: Harvard University Press, 2007), 374. 
społeczeństwo ${ }^{26}$. McDowell przypomina nam jednak, że normatywność przekonania polega na tym, iż może być ono właściwie bądź niewłaściwie przyjęte względem stanu rzeczy. Na tym również polega normatywność relacji umysłu i świata. Jednakże to jeszcze nie w tym miejscu ujawnia się różnica pomiędzy poglądami Sellarsa i Davidsona a stanowiskiem McDowella. Sam Davidson bowiem w A Coherence Theory of Truth zauważa, że „prawdziwość wypowiedzi opiera się tylko na dwóch rzeczach: na tym, co wypowiadane słowa znaczą oraz na tym, w jaki sposób świat jest zorganizowany" ${ }^{27}$. Oznacza to, że również Davidson, mimo swojego koherencjonistycznego stanowiska, przez normatywny charakter przekonań rozumie odpowiedniość wobec stanu rzeczy. Biorąc to pod uwagę musimy stwierdzić, że samo myślenie posiada normatywny charakter, lecz normy poprawności nie odnoszą się wyłącznie do tych tkwiących w logicznej przestrzeni racji, lecz sięgają także do tego, czego myślenie dotyczy. Myślenie, aby zostać w pełni rozważone $\mathrm{w}$ „normatywnym kontekście” musi być rozumiane nie tylko jako poprawne lub niepoprawne względem pewnych norm (wyznaczanych przez społeczeństwo), lecz również poprawne bądź niepoprawne względem przedmiotu, którego dotyczy.

McDowell nie widzi innego sposobu na wyjaśnienie relacji umysłu i świata, który pozwoliłby zachować pogląd, że przekonanie jest prawdziwe ze względu na to jaki jest świat, jeżeli nie pojmiemy doświadczenia zmysłowego jako „trybunału” zapośredniczającego relację umysłu i świata. Fakt, że umysł i świat wchodzą ze sobą w relacje i relacja ta polega na „odpowiedniości myśli wobec świata” jest dla McDowella czymś niedającym się podważyć, jeżeli w ogóle możemy mówić w sposób sensowny o myśleniu. Myślenie ma bowiem charakter intencjonalny, co oznacza, że jest ono zawsze o czymśs ${ }^{28}$. McDowell to ma na myśli, gdy nawiązuje do słynnego fragmentu z Krytyki czystego rozumu, że „[m]yśli bez treści naocznej są

${ }^{26}$ Por. tamże, 384-385: ,the essentially social character of conceptual thinking comes clearly to mind when we recognize that there is no thinking apart from common standards of correctness and relevance, which relate what I do think to what anyone ought to think. The contrast between »I« and »anyone « is essential to rational thought".

${ }^{27}$ "the truth of an utterance depends on just two things: what the words as spoken mean, and how the world is arranged”; Davidson, „A Coherence Theory of Truth and Knowledge”, 149.

${ }^{28}$ Powiązanie koncepcji McDowella $\mathrm{z}$ Brentanowskim pojęciem intecjonalności oraz fenomenologią Husserla wskazane zostało w: Lilian S. Alweiss, „Myth of the Given”, w: Mind in World. Essays on John McDowell's Mind and World, red. Janos Boros (Pécs, Hungary: Brambauer, 2005), 39-65. 
puste"29. Myśli, które nie odnoszą się do świata, a tym samym nie odnoszą się do doświadczenia zmysłowego, zdaniem McDowella, nie są w ogóle myślami ${ }^{30}$. Oznacza to, że przyjęcie minimalnego wkładu doświadczenia zmysłowego w modelu poznania empirycznego jest warunkiem istotnym, aby mówienie o takim poznaniu w ogóle miało sens. $\mathrm{Z}$ tego powodu twierdzę, że "minimalny empiryzm” McDowella powinien być rozumiany jako „model idealny poznania”, ustalający konieczne warunki dla konstruowania epistemologicznego modelu. Albowiem, jak twierdzi McDowell, jeżeli odrzucimy choćby minimalny wkład doświadczenia w poznanie, nie będziemy w stanie zrozumieć, w jaki sposób nasze myśli odpowiadają światu, a tym samym możemy pozbawić sensowność pojęcia poznania świata empirycznego. Z drugiej jednak strony, McDowell aprobuje istotność problemu z uzasadnieniem sądu na mocy doświadczenia zmysłowego, który został przedstawiony przez Sellarsa w Empiryzmie i filozofii umysłu. Autor Mind and World chce usunąc takie filozoficzne „napięcie”, przedstawiając konstruktywną część swojej filozofii, która wyraża się w twierdzeniu, że percepcja posiada pojęciową treść.

\section{Pojęciowa treść i epistemiczna wartość percepcji zmysłowej}

Za asumpt do dyskusji nad treścią percepcji można uznać podział treści epistemicznych dokonany przez Garetha Evansa w The Varieties of Reference na treść pojęciową (treść sądu) oraz niepojęciową (właściwą treść percepcyjną). Evans traktuje treść percepcyjną jako treść niepojęciową, która zawarta jest w bazowym stanie informacyjnym. Gdy podmiot formułuje sąd na podstawie tej treści konceptualizuje ją, dokonując tym samym przejścia w całkowicie odmienny stan informacyjny, posiadający już treść pojęciową ${ }^{31}$.

Odmienne stanowisko prezentuje McDowell. Według niego, treść percepcji jest w pełni pojęciowa. Nie ma zatem różnicy między dwoma stanami informacyjnymi: otrzymywania treści percepcyjnej i formułowania sądu. W Avoiding

${ }^{29}$ Immanuel Kant, Krytyka czystego rozumu, tłum. Roman Ingarden (Kęty: Wydawnictwo Antyk, 2001), 99.

${ }^{30} \mathrm{McD}$ owell, Mind and World, 4.

${ }^{31}$ Gareth Evans, The Varieties of Reference (New York: Oxford University Press, 1982), 227. 
the Myth of the Given daje klarowne rozwinięcie tej tezy. Podana zostaje tam przykładowa sytuacja: w polu widzenia podmiotu znajduje się ptak. Widzenie przez podmiot ptaka sprawia zaś, że podmiot w sposób nieinferencyjny wie, że ten ptak to kardynał. Albowiem nie jest tak, że wiedza, iż widziany ptak to kardynał została wywiedziona $z$ tego, jak obserwowany ptak wygląda. Taka wiedza musiałaby być inferencyjna, czyli byłaby wynikiem przeprowadzenia przez podmiot w myślach wnioskowania. Wziąłby on wówczas pod uwagę poszczególne cechy konkretnego przedmiotu, które zaobserwował i na ich podstawie sformułowałby wniosek: „Ten ptak to kardynał”. Wiemy jednak z doświadczenia, że wiedza o tym, że obserwowany przez nas przedmiot to pewien konkretny przedmiot, który potrafmy nazwać, pojawia się natychmiastowo. To może sugerować, że już w samym doświadczeniu ptaka jest coś, co sprawia, że wiemy, iż ten ptak to kardynał $^{32}$. Według wcześniejszej wersji koncepcji McDowella, wyrażonej w Mind and World, doświadczenie ptaka miałoby zatem charakter propozycjonalny i występowałoby w nim pojęcie „kardynał”, czyli mogło owo doświadczenie być wyrażane w zdaniu „To jest kardynał" ${ }^{33}$. Treść naszego doświadczenia byłaby zatem utożsamiona z treścią zdania wyrażającego fakt, że obserwowany przez nas przedmiot to kardynał.

Jednak zdaniem McDowella zawartego w Avoiding the Myth of the Given doświadczenie, mimo, iż jest pojęciowe, nie ma charakteru propozycjonalnego. Nie ma w nim zatem konkretnych pojęć, takich jak „kardynał”, które sprawiają, że możemy posiadać wiedzę wyrażoną w zdaniu „Ten ptak to kardynał” w sposób bezpośredni. Nie pociąga to jednak za sobą odrzucenia tezy obecnej w Mind and World, iż w doświadczeniu działają pojęciowe zdolności podmiotu, a co za tym idzie, że percepcja ma treść pojęciową ${ }^{34}$.

Koncepcja udziału pojęciowych zdolności na poziomie doświadczenia pochodzi (według McDowella) z właściwie zrozumianego modelu poznawczego zaproponowanego przez Kanta. Wedle klasycznego modelu Kantowskiego, poznanie empiryczne jest rezultatem współpracy „odbiorczości” (zmysłów) z „samorzutnością" (intelektem). Niemniej jednak według McDowella opis relacji owych

\footnotetext{
${ }^{32}$ Por. John McDowell, „Avoiding the Myth of the Given”, w: John McDowell: Experience, Norm and Nature, red. Jakob Lindgaard (Malden: Blackwell Publishing Ltd., 2008), 3-4.

${ }^{33}$ Oczywiście przy założeniu, że osoba spostrzegająca ptaka wie, czym charakteryzuje się ptak należący do gatunku kardynała.

${ }^{34}$ Por. tamże, 4.
} 
„dwóch pni poznania” nie powinien wyczerpywać się w stwierdzeniu, iż odbiorczość jest odpowiedzialna za treść, zaś intelekt jedynie za pomyślenie tej treści. McDowell zaznacza, że we właściwym rozumieniu współpraca polega na tym, iż pojęciowe zdolności podmiotu działają na treść naoczności już u jej „zarania”, a nie że są wypracowywane na uprzednio danej treści niepojęciowej ${ }^{35}$. W „Kantowskim modelu" McDowella treść doświadczenia zmysłowego może być zatem uznana za pojęciową, bo już u swych źródeł jest zapośredniczana przez pojęciową aktywność intelektu. Wówczas to także treść doświadczenia, a nie jedynie wiedza o przedmiocie, będzie rezultatem działania intelektu i zmysłowości. To dzięki ich „współpracy” na najbardziej fundamentalnym poziomie poznania mamy możliwość odebrania treści percepcyjnej ${ }^{36}$.

McDowell formułując tę tezę powołuje się na fragmenty Krytyki czystego rozumu dotyczące dedukcji czystych pojęć intelektu. W jednym z później opublikowanych esejów pisze: „Dla Kanta naoczności stanowią całość z sądami w tym znaczeniu, że to, co czyni ich przedmiotowe znaczenie możliwym jest fakt, iż posiadają one kategorialną jedność”37, a to oznacza, że „treść naoczności jest tego samego rodzaju, co treść sądu" ${ }^{38}$. Chodzi zatem o znaną myśl, że u Kanta intelekt czyni możliwym wystąpienie jakiegokolwiek empirycznego przedstawienia. Przedstawienia, które, co trzeba podkreślić, poprzedza wszelką dyskursywną konceptualizację i ją umożliwia. Czyni to zaś poprzez syntezowanie danych doznaniowych do postaci przedmiotu. Czysto zmysłowe oglądanie jest, jak pisze Kant, „tylko doznawaniem”39. Takie doznawanie cechuje się odbiorem „ślepej”, różnorodności, zaś, jak pisze dalej Kant, „wszelkie wiązanie jest czynnością intelektu bez względu na to, czy jesteśmy jej świadomi, czy nie, i czy jest to powiązanie różnorodnych danych naocznych, czy też rozmaitych pojęç" ${ }^{\prime 40}$, „[n]adamy mu ogólną

${ }^{35}$ Por. McDowell, Mind and World, 9.

${ }^{36}$ Por. tamże, 10.

${ }^{37}$ „For Kant, intuitions belong together with judgments in this respect: what makes their objective purport possible is that they have categorial unity”. John McDowell, „Conceptual Capacities in Perception," w: Having the World in View. Essays on Kant, Hegel, and Sellars, red. John McDowell (Cambridge: Harvard University Press, 2009), 127.

${ }^{38}$ „the content of intuitions is of the same general kind as the content of judgments”; tamże.

${ }^{39}$ Kant, Krytyka czystego rozumu, 153.

${ }^{40}$ Tamże, 154. 
nazwę syntezy, ażeby [...] zaznaczyć, iż nie możemy sobie niczego przedstawić jako powiązanego w przedmiocie nie powiązawszy go uprzednio samemu"41.

W treści wyżej zacytowanych fragmentów ujawnia się kilka interesujących dla niniejszego wywodu kwestii. Należy zauważyć, że „wiązanie” różnorodności doznaniowej do postaci jednolitego, a przez to intelligibilnego, przedstawienia może odbywać się zarówno w sposób świadomy jak i nieświadomy. Kantowi zatem, podobnie jak McDowellowi, nie chodzi o konceptualizację niepojęciowej treści do postaci pojęcia (a więc odniesienie się do tej treści i przekształcenie jej), lecz o samo pojawienie się percepcyjnej treści, które jest uprzednie względem wszelkich dyskursywnych jej konceptualizacji. $\mathrm{Z}$ tego powodu w Mind and World McDowell pisze, że „[p]owinniśmy rozumieć to, co Kant nazywa naocznością [...] nie jako tylko uzyskiwanie poza-pojęciowych danych, lecz jako rodzaj zdarzenia bądź stanu, który już posiada pojęciową treść”42. Takie działania nie są dyskursywnymi aktywnościami ani nawet, jak pisze dalej McDowell, „rezultatami pierwszego kroku w ramach przestrzeni racji” ${ }^{43}$. Treść tego rodzaju jest już „posiadana” przez dane doświadczenia zmysłowego. U Kanta takie „wiązanie” jest tej samej natury w dwóch możliwych przypadkach. Stany te różnią się od siebie tym, że jedne mogą być dyskursywne (w przypadku myślenia pojęciowego), inne zaś niedyskursywne (w przypadku syntezowania doznań do postaci przedstawienia przedmiotu empirycznego). Oba jednak stany możemy określić jako pojęciowe, ponieważ, wchodząc w zakres syntezującej zdolności intelektu, przebiegają w taki sam sposób.

W Avoiding the Myth of the Given McDowell podtrzymuje twierdzenie, że zdolności, które umożliwiają „pojawienie się” przedstawienia są tego samego rodzaju, co pojęciowe zdolności, działające podczas formułowania sądów ${ }^{44}$. W Mind and World percepcja posiada oprócz tego propozycjonalną treść: $\mathrm{w}$ doświadczeniu podmiot widzi, że rzeczy są takie-a-takie, czyli widzi coś, o czym może wydać $\mathrm{sąd}^{45}$. Dodatkowo, przeciwstawiając się twierdzeniom Evansa o tym, że treść percepcji jest szczegółowa do tego stopnia, że nie może być całkowicie ujęta w pojęcia,

${ }^{41}$ Tamże.

${ }^{42}$ „We should understand what Kant call „intuition” [...] not as a bare getting of an extra-conceptual Given, but as a kind of occurrence or state that already has conceptual content". McDowell, Mind and World, 9.

${ }^{43}$ „results of a first step within the space of reasons”; tamże.

${ }^{44}$ Por. McDowell, Avoiding the Myth of the Given, 5.

${ }^{45}$ Por. tenże, Mind and World, 9. 
McDowell twierdzi, iż treść percepcji zawiera wszystko to, co podmiot posiada na poziomie sądu o tej treści ${ }^{46}$. Z kolei w Avoiding the Myth of the Given McDowell jest zdania, że treść percepcji nie jest propozycjonalna, lecz naocznościowa [intuitional $]^{47}$.

Odrzucenie przez McDowella propozycjonalnego charakteru treści percepcji jest wynikiem uświadomienia sobie, że taki jej charakter niesłusznie zbliża ją myślenia dyskursywnego. Między tym, co dyskursywne, a tym co naocznościowe, zdaniem McDowella, zachodzi radykalna różnica: treść dyskursywna jest artykułowalna, podczas gdy treść naocznościowa już nie ${ }^{48}$. W dyskursywnym myśleniu, czyli formułowaniu sądów lub wnioskowań, podmiot łączy ze sobą znaczenia. W związku z tym należy stwierdzić, że treść dyskursywnych aktywności to kombinacja (tworzona w rezultacie świadomego, podmiotowego działania) znaczących wyrażeń ${ }^{49}$. W tym miejscu McDowell pokazuje, że propozycjonalność jest ściśle związana z dyskursywnością, ponieważ to, co propozycjonalne jest zawsze konstrukcją składającą się ze znaczeń. Inaczej jest jednak z treścią naocznościową, która, zdaniem McDowella jest dana. Treść doświadczenia nie może być konstruowana w ramach dyskursywnej aktywności podmiotu, nie może być także wynikiem wnioskowania. Jest ona podmiotowi dana, jednak jej jednorodny charakter sugeruje, że w procesie „otrzymywania” jej przez podmiot zadziałały jego pojęciowe zdolności, dzięki którym jest ona już przygotowana do bycia treścią sądu. Sam fakt „gotowości” do stania się treścią sądu jest dla McDowella oznaką jej pojęciowego charakteru.

Treść doświadczenia zmysłowego jest podana podmiotowi w postaci, dzięki której ów podmiot może ją sprowadzić do znaczenia, z którego następnie, na poziomie myślenia dyskursywnego, może sformułować sąd. Taka intelligibilna postać naoczności jest wynikiem łączenia doznaniowej różnorodności treści naocz-

${ }^{46}$ Krytyką koncepcji niepojęciowej treści percepcji w odniesieniu do Evansa McDowell zajmuje się w trzecim rozdziale Mind and World. Por. tamże, 46-66.

${ }^{47}$ Chodzi tutaj o Kantowskie Anschauung, które w anglojęzycznej tradycji tłumaczy się jako „intuition”. Por. tamże, 4. W tłumaczeniu Krytyki czystego rozumu Romana Ingardena Anschauung to oczywiście „naoczność”. Ze względu na mocne ugruntowanie pojęcia „naoczności” w polskich dyskusjach wokół Kanta, pisząc o „intuitional content” McDowella zachowam Ingardenowski sposób przekładania tego terminu.

${ }^{48}$ Por. tamże, 6.

${ }^{49}$ Por. tamże. 
nej do postaci jednorodnego przedstawienia. Wedle takiego rozumienia Kantowskiego „powiązania tego, co różnorodne” w doświadczeniu nie jesteśmy świadomi poszczególnych danych zmysłowych, z których dopiero wnioskujemy o obserwowanym przez nas przedmiocie, lecz znajduje się tam już gotowe powiązanie tych danych. Świadomi jesteśmy jednorodnego przedstawienia i to sprawia, że możemy wydać o nim sąd. Takie przedstawienie jest bowiem równoznaczne $\mathrm{z}$ faktem, który na poziomie formułowania sądu jest wyrażany w postaciach, o których pisał Sellars, a mianowicie: „coś jest takie-a-takie” lub „coś pozostaje w pewnej relacji do czegoś innego”. Poznanie zaś również wspominanych przez Sellarsa „indywiduów”, albo „danych zmysłowych" rozważanych w odosobnieniu jest jedynie rezultatem dalszej pojęciowej analizy ${ }^{50}$.

Takie syntezowanie tego, co różnorodne na poziomie doświadczenia odbywa się zaś w takim sam sposób, w jaki odbywa się syntezowanie znaczeń na poziomie myślenia dyskursywnego. Sąd o pewnym fakcie może być zatem rozumiany analogicznie do przedstawienia - jest on w takim przypadku również jednolitym mentalnym zdarzeniem powstałym poprzez powiązanie różnych znaczeń, których rozważenie w odosobnieniu także stanowi dziedzinę analizy. Treść percepcji jest zatem potencjalnie propozycjonalna, bo w jej unifikacji w grę wchodzą te same zdolności, co w procesie „łączenia znaczeń”, gdy podmiot formułuje sąd. Pojęciowość treści percepcji polega zaś na tym, że treścią percepcji jest już to, co zostało zunifikowane w wyniku działania pojęciowych zdolności. Jest to zatem treść innego rodzaju, niż treść sądu, jednak wciąż pozostaje treścią o charakterze myślowym. Dzięki temu możliwe jest „przełożenie” tej treści w sposób nieinferencyjny na język pojęć, na które składa się treść myślenia.

\section{Wnioski}

Biorąc pod uwagę wyżej przedstawione kwestie twierdzę, że wartość epistemiczna doświadczenia zmysłowego w stanowisku McDowella polega na jego potencjalnej propozycjonalności. Taki charakter doświadczenia wynika zaś z jego pojęciowej treści.

${ }^{50}$ Idę tutaj za sugestią Kanta, że unifikacja poprzedza analizę, bo „gdzie intelekt niczego uprzednio nie powiązał, tam nie może niczego rozwiązać”, por. Kant, Krytyka czystego rozumu, 154. 
Jeżeli w koncepcji doświadczenia ograniczymy się wyłącznie do wskazania na jego czysto doznaniowy charakter i będziemy utrzymywać, że posiada ono epistemiczną wartość, wówczas wprowadzimy do naszej epistemologii „mit danych”. Rozwiązanie, w którym proponuje się uwzględnienie udziału doświadczenia jedynie jako przyczyny poznania (odrzucając tym samym jego wartość epistemiczną) również jest niesatysfakcjonujące, ponieważ nie wyjaśnia jak możliwa jest normatywna relacja odpowiedniości pomiędzy wiedzą empiryczną i światem. Punktem wspólnym tych propozycji jest przyjęcie koncepcji doświadczenia jako działania irracjonalnego, charakteryzującego się wyłącznie odbiorczością. $Z$ tego powodu McDowell próbuje ocalić epistemiczną wartość doświadczenia zmysłowego przeformułowując jego koncepcję. W związku z tym proponuje perspektywę, wedle której należy ono do logicznej przestrzeni racji, ponieważ w związku ze swoim pojęciowym charakterem może wchodzić w racjonalne relacje z przekonaniami.

Jakkolwiek twierdzenie z Avoiding the Myth of the Given o potencjalnej propozycjonalności doświadczenia może być nie do końca satysfakcjonujące, to takie „osłabienie” koncepcji względem Mind and World, posiada istotne przesłanki. Treść percepcji może być jedynie potencjalnie propozycjonalna, ponieważ jeżeli chcemy zachować bierny charakter doświadczenia zmysłowego, nie możemy zakładać, iż treść ta konstruowana jest w ramach dyskursywnej aktywności. Doświadczenie zaś, wedle modelu idealnego, jakim jest „minimalny empiryzm”, ma stanowić „trybunał”, dzięki któremu możliwa jest odpowiedniość myślenia i świata. Dyskursywna aktywność formułowania sądów staje przed osądem doświadczenia, które swoją treść czerpie ze świata. Taka treść posiada jednak pojęciowy charakter: nie jest bowiem tak, że doświadczenie dostarcza nam pojedynczych doznań, z których następnie, na drodze rozumowania, formułujemy wiedzę o pewnym fakcie. Wyróżnianie z przedstawienia poszczególnych jego komponentów w postaci danych zmysłowych jest wyłącznie pojęciową analizą tego przedstawienia. Twierdzenie o ich realności, pierwotności oraz nieredukowalności (w odróżnieniu od wiedzy propozycjonalnej, która w takim przypadku będzie konstruowana przez podmiot, wtórna i przez to podlegająca analizie) jest nieuzasadnione, komplikuje obraz oraz generuje problemy na gruncie epistemologicznym. W zamian za to możemy przyjąć, że to, co zostaje dane nam w doświadczeniu jest fakt, dzięki temu, że nasze postrzeganie świata jest współokreślane przez nasze pojęciowe zdolności, które odpowiadają również za formułowanie przekonania o tym fakcie na poziomie myślenia dyskursywnego. 
Dzięki przyjęciu takiej strategii udaje się wykazać, że doświadczenie zmysłowe oraz sądy formułowane na jego podstawie wchodzą ze sobą w racjonalne, a nie tylko przyczynowe stosunki. Racjonalność myślenia i doświadczenia jest możliwa dzięki pojęciowości treści doświadczenia. W ten sposób doświadczenie jest potencjalnie propozycjonalne. Jeżeli zaś doświadczenie zmysłowe jest takie, to może być ono również epistemicznie wartościowe i stanowić uzasadnienie sądu.

\section{Bibliografia}

Alweiss, Lilian S. „Myth of the Given”. W: Mind in World. Essays on John McDowell's Mind and World, red. Janos Boros, 39-65. Pécs, Hungary: Brambauer, 2005.

Davidson, Donald. „A Coherence Theory of Truth and Knowledge”. W: Subjective, Intersubjective, Objective, red. Donald Davidson, 137-57. Oxford: Clarendon Press, 2001.

Davidson, Donald. „O pojęciu schematu pojęciowego”. Tłum. Jarosław Gryz. W: Empiryzm współczesny, red. Barbara Stanosz, 281-97. Warszawa: Wydawnictwo Uniwersytetu Warszawskiego, 1991.

deVries, Willem A. i Timm Triplett. Knowledge, Mind and the Given. Indianapolis: Hackett Publishing Company, Inc., 2000.

Evans, Gareth. The Varieties of Reference. New York: Oxford University Press, 1982.

Kant, Immanuel. Krytyka czystego rozumu. Tłum. Roman Ingarden. Kęty: Wydawnictwo Antyk, 2001.

McDowell, John. „Avoiding the Myth of the Given”. W: John McDowell: Experience, Norm and Nature, red. Jakob Lingaard, 1-15. Malden: Blackwell Publishing Ltd., 2008.

McDowell, John. „Conceptual Capacities in Perception”. W: Having the World in View. Essays on Kant, Hegel, and Sellars, 127-47. Cambridge: Harvard University Press, 2009.

McDowell, John. Mind and World. Cambridge: Harvard University Press, 1996.

McDowell, John. „Why is Sellars Essay Called 'Empiricism and Philosophy of Mind '”. W: Empiricisim, Perceptual Knowledge, Normativity, and Realism, red. Willem A. deVries, 932. Oxford: Oxford University Press, 2009.

O'Shea, James R. „On the Structure of Sellar's Naturalism with a Normative Turn”. W: Empiricisim, Perceptual Knowledge, Normativity, and Realism, red. Willem A. deVries, 188- 210. Oxford: Oxford University Press, 2009.

O'Shea, James R. Wilfrid Sellars: Naturalism with a Normative Turn. Cambridge: Polity Press, 2007.

Quine, Willard Van Orman. Zlogicznego punktu widzenia. Tłum. Barbara Stanosz. Warszawa: PWN, 1969. 
Rorty, Richard. Filozofia a zwierciadło natury. Tłum. Michał Szczubiałka. Warszawa: Spacja: Fundacja Aletheia, 1994.

Sellars, Wilfrid. „Empiryzm i filozofia umysłu”. Tłum. Jarosław Gryz. W: Empiryzm współczesny, red. Barbara Stanosz, 173-257. Warszawa: Wydawnictwo Uniwersytetu Warszawskiego, 1991.

Sellars, Wilfrid. „Philosophy and the Scientific Image of Man”. W: In the Space of Reasons. Selected Essays of Wilfrid Sellars, red. Kevin Scharp i Robert B. Brandom, 369-411. Cambridge: Harvard University Press, 2007.

Westphal, Keeneth R. „Contemporary Epistemology: Kant, Hegel, McDowell”. W: John McDowell: Experience, Norm, and Nature, red. Jakob Lindgaard, 124-152. Malden: Blackwell Publishing Ltd., 2008.

Woleński, Jan. Epistemologia: poznanie, prawda, wiedza, realizm. Warszawa: Wydawnictwo Naukowe PWN, 2005.

\section{Summary \\ The epistemic value of perceptual experience. \\ Wilfrid Sellars vs. John McDowell}

The author reflects on the epistemic value of perceptual experience. Quoting John McDowell's conceptual content of perception as an example, he argues that Wilfrid Sellars' criticism of empiricism is not tantamount to negating the meaningfulness of the epistemological foundationalist idea entirely. He concludes that rehabilitating the value of perception in justification of knowledge is therefore possible after reformulating the notion of perceptual experience. For by accepting the idea of conceptual content of perception and its consequence in the shape of a potential propositional content of experience it could be proved that perception can be engaged in a rational (and not only causal) relationship with a subject's beliefs. And that justifies the epistemological foundationalist idea that knowledge has indeed an external and epistemically valuable footing.

Keywords: John McDowell, Wilfrid Sellars, Empiricism and Philosophy of Mind, Mind and World, conceptual content of perception, foundationalism, epistemology, empiricism, value, logical space of reasons 


\section{Zusammenfassung}

\section{Epistemischer Wert der sinnlichen Erfahrung. Wilfrid Sellars versus John McDowel}

Der Artikel bildet einen Versuch, über den epistemischen Wert der sinnlichen Erfahrung nachzudenken. Indem ich als Beispiel den Begriffsinhalt der Wahrnehmung bei John McDowell nehme, versuche ich nachzuweisen, dass die von Wilfrid Sellars ausgeübte Kritik des Empirismus nicht vollständig den Sinn der Idee einer fundamentalistischen Epistemologie verneint. Ich glaube damit, dass es möglich ist, den Wert der Wahrnehmung in der Rechtfertigung des Wissens nach der Umformulierung des Entwurfs der sinnlichen Erfahrung zu rehabilitieren. Wenn wir nämlich die Idee des Begriffsinhalts der Wahrnehmung und ihre Folgen in Gestalt von potentieller Propositionalität des Erfahrungsinhalts annehmen, gelingt es uns aufzuzeigen, dass die Wahrnehmung ein rationales (und nicht ausschliesslich kausales) Verhältnis mit den Überzeugungen des Subjekts eingehen kann. Dies rechtfertigt hingegen die Ideen der fundamentalistischen Epistemologie von einer äusseren und epistemisch wertvollen Grundlage des Wissens.

Schlüsselworte: John McDowell, Wilfried Sellars, Empirismus und die Philosophie des Geistes, Mind and World, der Begriffsinhalt der Wahrnehmung, erkenntnistheoretischer Fundamentalismus, Epistemologie, Empirismus, Wert, logischer Raum der Gründe

Information about Author:

MICHAŁ BOCHEN, MA in philosophy; adress for correspondence: Pl. Marii Curie-Skłodowskiej 4, PL 20-031 Lublin; e-mail: faumaks@gmail.com 